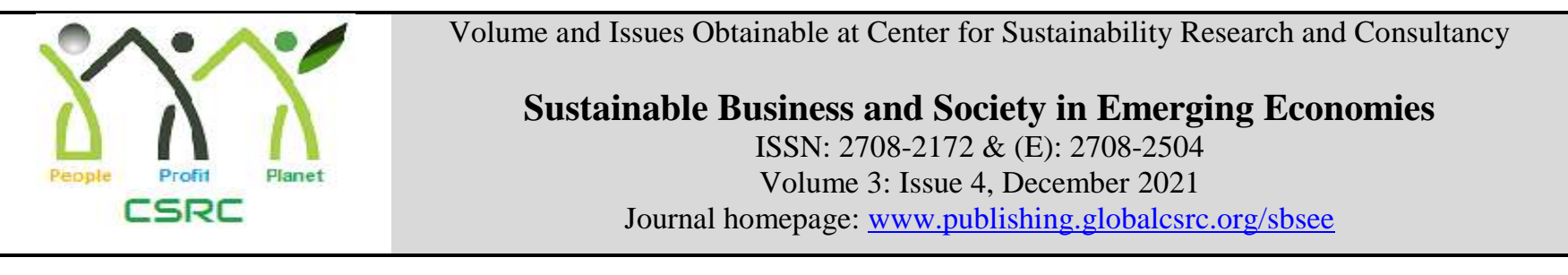

\title{
Fiscal Decentralization and Social Service Delivery: An empirical Analysis of Balochistan
}

*Chakar Khan, PhD Scholar, Faculty of Management sciences, International Islamic University, Islamabad, Pakistan

Lecturer at University of Balochistan, Quetta, Pakistan

Muhammad Akram, Assistant Professor, International Institute of Islamic Economics, International Islamic University Islamabad, Pakistan

Imran Farooq, National savings officer at National savings, Ministry of Finance, Islamabad, Pakistan

${ }^{\star}$ Corresponding author's email address: chakarjan@yahoo.com

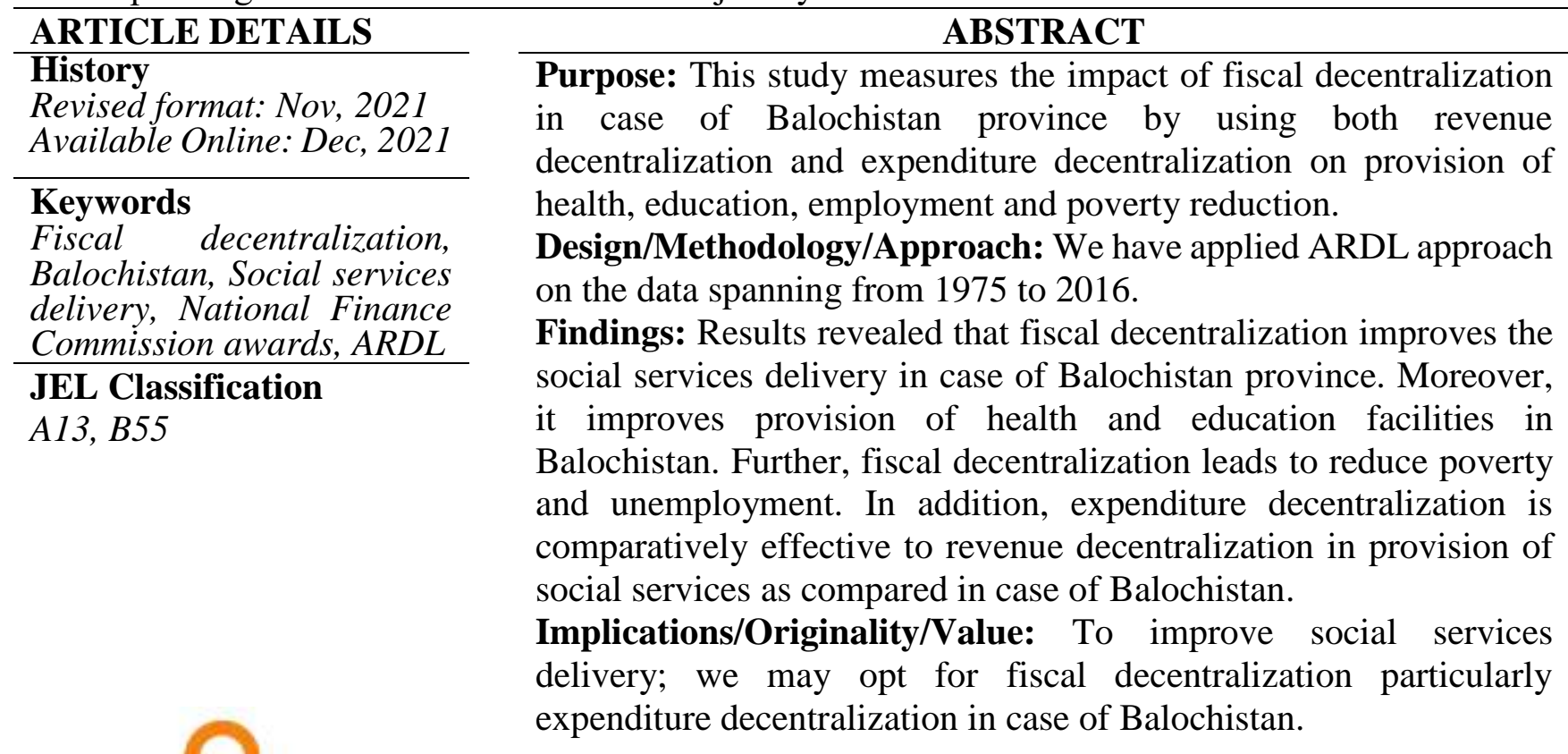

(C) 2021 The authors, under a Creative Commons Attribution-

NonCommercial- 4.0

Recommended citation: Khan, C., Akram, M. and Farooq, I. (2021). Fiscal Decentralization and Social Service Delivery: An empirical Analysis of Balochistan. Sustainable Business and Society in Emerging Economies, 2 (2), 471-483

\section{Introduction}

Fiscal decentralization is key to development and growth of the economies particularly, through effective use and identification of the resources at local levels. Fiscal decentralization improves the social services delivery in the society and ultimately leads more development and improves the living standard of the people living in a country. Existing literature provides much evidence on the importance and effectiveness of fiscal decentralization in development of countries by analyzing the impact of fiscal decentralization on provision of social services delivery (Ansari, Chaudary and Faraidi, 2012; Ahmed and Lodhi, 2013; Nazar and Faridi 2013 and Ahmed, 2012). However, in previous literature, different researchers have used different proxies of fiscal decentralization to measure its impact on the services delivery. 
Specifically, existing studies have focused on the impact of fiscal decentralization on education and health (Ahmed and Lodhi, 2013: Saavedra, 2010; Apkan 2011). However, the impact of Fiscal decentralization of varies from country to country. Some studies report positive impact whereas the other studies report negative impact of fiscal decentralization on poverty (Bengali et al 2001; Ahmad, 2013), health (Sha, 2007; Sadiq and Mehmood, 2010 and Zou and Zhang, 1998) and education (Zia, 2014; Hector, 2006; and Fjeldstad, 2001). So, overall the existing literature presents mixed results on the impact of fiscal decentralization. Therefore, results of one country cannot be generalized to another country because country specific conditions vary from country to country. Moreover, the very limited work has done on this issue in case of Pakistan, particularly, Balochistan. Therefore, this study initiated to measure the impact of fiscal decentralization in case of Balochistan province. Specifically, in this paper we have tested that whether fiscal decentralization improves the services delivery in case Balochistan province. For this purpose, we have considered both revenue decentralization and expenditure decentralization to measure the impact of fiscal decentralization on provision of health, education, employment and on poverty reduction.

Fiscal decentralization in Pakistan is taken in form of NFC (National Finance Commission) Awards. There is increasing trend in NFC award share of the Sindh, KPK and Balochistan but decreasing trend in NFC award share of Punjab from $60 \%$ to $51 \%$, under horizontal resource distribution because of change in criterion of horizontal distribution of resources among the provinces. The parameter which was added later includes Revenue generation, Poverty, area wise, backwardness and other factors, before $7^{\text {th }}$ NFC Award 2009, the main parameter was only population.

Table 1. Summary of the Provinces share NFC, S Awards from the year 1974 to 2009

NFC Awards \& year

Provinces and their respective shares in percentage

\begin{tabular}{ccccc} 
& Punjab & Sindh & KPK & Balochistan \\
\cline { 2 - 5 } $\mathbf{1}^{\text {st }} \mathbf{( 1 9 7 4 )}$ & 60.25 & 22.50 & 13.39 & 3.86 \\
\hline $\mathbf{2}^{\text {nd }}(\mathbf{1 9 7 9 )}$ & 57.97 & 23.34 & 13.39 & 5.30 \\
\hline $\mathbf{3}^{\text {rd }}(\mathbf{1 9 8 5})$ & 57.97 & 23.34 & 13.39 & 5.30 \\
\hline $\mathbf{4}^{\text {th }}(\mathbf{1 9 9 0})$ & 57.88 & 23.28 & 13.54 & 5.30 \\
\hline $\mathbf{5}^{\text {th }}(\mathbf{1 9 9 6})$ & 57.88 & 23.28 & 13.54 & 5.30 \\
\hline $\mathbf{6}^{\text {th }} \mathbf{( 2 0 0 0 )}$ & 57.88 & 23.28 & 13.54 & 5.30 \\
\hline $\mathbf{7}^{\text {th }}(\mathbf{2 0 0 9})$ & 51.74 & 24.55 & 14.62 & 9.09 \\
\hline
\end{tabular}

Source: National Finance Commission Report (2009)

\section{Literature Review}

Tiebout (1956) and Musgrave (1959) says that local people have access more effective and better information regarding local condition than central government. They are well aware about the local condition what needs to be done on the grass roots level. Similarly, Meager (1999) explored that fiscal decentralization has positive impact on the economic growth, economic efficiency, better infrastructure and public services delivery. Ultimately, it is used to address problem of social services sector to remove the hinder of decision making, monotony and implementation process. Additionally, it gives the local authorities to do something extra that benefits the local people of the respective areas by decentralization of revenue and expenditure in this regard. Moreover, Asfaw et al. (2007) checked the impact of fiscal decentralization on infant mortality in India using the data from 1990 to 1997; they concluded that the impact of fiscal decentralization on infant mortality rate is significant and positive. However, effectiveness of fiscal decentralization depends upon the political decentralization in the country or in other words it is important to give political decentralization as well giving fiscal decentralization.

Furthermore, kardar (2001) works on the local government finance in Pakistan. He found that high present level of centralization has failed to provide adequate level of social services. Secondly, he suggested 
devolving important services such as health, education and water supply to the local level and more financial devolution from the central and provincial level to the local level. Likely, Mehmood and Sadiq (2010) on his research work in Pakistan case found out that fiscal decentralization has significantly and positively affect the human development index resultantly by improving the health care facilities. Likely, Ahmad (2012) found that fiscal decentralization has significantly a positive impact on poverty reduction in Pakistan. Conclusively, fiscal decentralization improves the health care outcomes by reducing the infant mortality rate and by developing more providing more medical facilities and hospitals in the provinces. Similarly, Ahmed and Lodhi (2013) worked on fiscal decentralization and its impact on health outcome. They concluded that it has positive impact on the health care outcomes in the provinces of Pakistan. In addition, Fiscal decentralization of health is weaker in Balochistan and KPK case as compare to the other provinces while fiscal decentralization is more effective on health care in Punjab and Sindh case because of the better fiscal space and improved infrastructure. Furthermore, good quality of governance has a positive impact on the basic health care. In addition, Faraidi, Chaudary and Ansari (2012) check the fiscal decentralization role in generating opportunities for employment in Pakistan by using ordinary least square method from 1972-2009. The result identified two factors that are hinder in way of creating employment opportunity are poverty and inequality. When the delegation of authority flows from central government to provincial or local government resultantly positive association between fiscal decentralization and social services delivery. The economic efficiency is attained through it by achieving economy of scale. Thus, employment opportunities are generated and reduces inequality gap. Ultimately, poverty reduces through aforementioned process and techniques. Contrary, giving more autonomy to provinces in form of revenue decentralization is ineffective because the local or provincial governments are less efficient in tax due to scale of operation and human capital deficiency comparatively to central government. Thus, negatively effect on the social services delivery particularly unemployment and poverty. Comparatively, the expenditure decentralization is more effective to revenue decentralization pertaining to employment creation and pro poverty policies.

On the other side, some researchers have strong criticism regarding decentralization of health care services and evidence against the health services decentralization is of equally strong as well. Such as Trumpt et al. (1999) stated that local health planner and resources allocators has decrease the proportion of health care spending with the increase in another public goods spending. Furthermore, Pritchete (1996) and Inchaestion (2000) found that in Mexico and Jordan despite of the decentralization of health care services; the infant mortality rate remains unchanged due to the decentralization of health care sector in these countries. In addition, Khemani (2001) studied Nigeria, the situation got worsen and it causes a further deterioration of an already poor and low-quality standards of health services delivery due to disruption and mismanagement in the local level government because they are unable to efficiently utilize the resources because they are not trained and competent. Ultimately, inadequate accountability, inefficient management, mismanagement in handling of resources, and lacks accountability and administrative capacity the policy of decentralization on health care services. It does not have any impact on the health care outcomes and further deteriorates health sectors; which has already poor and low-quality standards of health care services. Ultimately, it has negative impact rather than having a positive impact on the provisions of health care due to decentralized. Similarly, Zou and Zhang (1998) found negative association with fiscal decentralization (FD) and health care outcomes in china. In contrary view of decentralization, some researches empirical result shows that the financial constraints must be released by the government for betterment of educational outcomes. Contrary, Carnoy and Moora (2000) found that without financial support from the central government to the local government; the educational decentralization further deteriorates education outcomes. For example, the decentralization of education in chili and Brazil further deteriorates the education outcome. Moreover, Zhang and Zou (1998) found negative association with fiscal decentralization and education outcomes in china. Literacy rate does not get improved due to fiscal decentralization.

\section{Methodology and Data}

The empirical model is derived from Robalino et al. (2002) model equation 6 and equation 7. 
$\mathrm{M}=\alpha_{0}+\alpha_{1} \varphi+\alpha_{2} S$

$\mathrm{M}$ is social service variable, $\alpha_{2}$ Depicts the relative level of efficiency for resource allocation by central and state planners, it is a function, that narrates about state own development and structural characters like state resources and population. As hypothesis is formulated as under;

$\alpha_{2}=\alpha_{0}+X \beta$

Whereas, $\mathrm{X}$ is row vector of structural characters of state while $\beta$ is row vector to be estimated.

For analysis, the impact of NFC award share on the social services delivery in Balochistan. The variables of the social services delivery are health, education, unemployment and poverty.

Social services $(\mathrm{SS})=$ (education, access to health services, unemployment and poverty)

Akpan (2011) used two approaches for measuring of fiscal decentralization, are given below.

Revenue decentralization= provincial revenue / central revenue and

Expenditure decentralization= provincial expenditure / central expenditure

If the ratio of provincial revenue to central revenue or provincial expenditure to central expenditure is much greater than central revenue or central expenditure it depicts that there is more fiscal decentralization. If this ratio is low, it means that there is high fiscal centralization. It is expressed in ratio form.

ARDL approach is applied on the data spanning from 1975 to 2016. The data of fiscal decentralization, PSDP, expenditure on education is collected from ministry of finance, Islamabad and provincial ministry of finance, Quetta to calculate both ratio of revenue decentralization and expenditure decentralization. The data of the infant mortality was taken from UNDP and Kaiser Bengali. The data of inflation (used for misery index calculation) is taken from State Bank of Pakistan, planning and development department of Balochistan, and statistical Bureau of Pakistan and World Bank.

\section{Results and Discussion}

The research is based on the time series data, so Augmented Ducky Fuller (ADF) test is used to check the stationary of the variables. The results of the unit root tests are given below.

Table: 2. Unit Root Results

\begin{tabular}{ccc}
\hline List of Variables & I $(\mathbf{0})$ & IDF Results \\
\cline { 2 - 3 } & & $-5.787^{* * *}$ \\
\hline RD & $-5.594^{* * *}$ \\
\hline ED & $-5.535^{* * *}$ \\
\hline PGR & $-1.905^{* * * *}$ \\
\hline POV & $-3.487 * * *$ \\
\hline PSDP & $-5.281^{* * *}$ \\
\hline EDE & $-7.224^{* * *}$ \\
\hline IMR & $-4.948^{* * *}$ \\
\hline PCI & $-3.369^{*}$ & \\
\hline MI & $-4.035^{* * *}$ & \\
\hline UER & $-1.636^{*}$ & \\
\hline$*$ shows significance at 10\% level, ** significance at 5\% level, *** significance at 1\% level
\end{tabular}

The unemployment rate (UER), per capita income (PCI), and misery index (MI) are stationary at level while other variables revenue decentralization (RD), expenditure decentralization (ED), Infant mortality rate (IMR), poverty (POV), maternity center and child welfare center (MCWC), population growth rate (PGR), expenditure on education (EDE) and Public-sector development program (PSDP) are stationary at first difference. The aforementioned variables are taken in log form.

Few of the variables are stationary at first difference and most of them, are stationary at level and no variables are stationary at second difference. So, ARDL model is used for the estimation of the model.

\section{Fiscal Decentralization and Health Outcome}

To analyze the impact of fiscal decentralization on health outcome of Balochistan. 
$\log \mathrm{IMR}_{\mathrm{it}}=\beta_{0}+\beta_{1} \operatorname{logED_{it}}+\beta_{2} \operatorname{logRD_{it}}+\beta_{3} \log \mathrm{MCWC} \mathrm{C}_{\mathrm{it}}+\beta_{4} \log \mathrm{PSDP}_{\mathrm{it}}+\beta_{5} \log P C \mathrm{I}_{\mathrm{it}}+\beta_{6} \operatorname{logEDE} \mathrm{E}_{\mathrm{it}} \mathrm{e}_{\mathrm{it}} \cdot$ ..........EQ 1

The optimal lag length is one as per three information criteria, where the minimum value of lag is got at first lag and Akaike Information Criteria is used for selection of optimal lag length. The result of each Information Criteria is given below.

Table: 4. F Bound Test Results

\begin{tabular}{|c|c|c|c|c|c|c|}
\hline \multirow{2}{*}{$\begin{array}{l}\text { F-Test } \\
\text { value }\end{array}$} & \multirow{2}{*}{$\begin{array}{c}\text { NO of } \\
\text { Parameters }\end{array}$} & \multirow[t]{2}{*}{ Lag length } & \multirow{2}{*}{$\begin{array}{c}\text { Significance } \\
\text { level }\end{array}$} & \multicolumn{2}{|c|}{ Bound test critical values } & \multirow[t]{2}{*}{ Decision } \\
\hline & & & & I (0) & I (1) & \\
\hline \multirow[t]{3}{*}{4.42} & 6 & 1 & $1 \%$ & 2.88 & 3.99 & Co-integrated \\
\hline & & & $5 \%$ & 2.27 & 3.28 & Co-integrated \\
\hline & & & $10 \%$ & 1.99 & 2.94 & Co-integrated \\
\hline \multicolumn{7}{|c|}{ Table: 3. Lag Length Selection Criteria Results } \\
\hline LAG & \multicolumn{2}{|r|}{ AIC } & \multicolumn{2}{|r|}{ SIC } & \multicolumn{2}{|r|}{ HQIC } \\
\hline 1 & \multicolumn{2}{|r|}{$-23.450^{*}$} & \multicolumn{2}{|r|}{$-21.061^{*}$} & \multicolumn{2}{|r|}{$-22.593^{*}$} \\
\hline 2 & \multicolumn{2}{|r|}{-22.779} & \multicolumn{2}{|c|}{-18.300} & \multicolumn{2}{|r|}{-21.172} \\
\hline \multicolumn{7}{|c|}{ *Indicates lag order selected by criterion } \\
\hline
\end{tabular}

AIC Akaike Information Criteria

SIC Schwarz Information Criteria

HQIC Hannan Quin Information Criteria

When the $\mathrm{F}$ test statistic is greater the lower bound value and upper bound value, it means that there is cointegration exist among the variables. The result of the $\mathrm{F}$ bound test is given below.

After determining the co-integration among variables of the equation 1, the long run parameters are estimated on basis of the lag length selected through AIC. Its results are given below Table.

\begin{tabular}{|c|c|c|c|}
\hline \multicolumn{4}{|c|}{ Table: 5. Long Run Parameters \& Short Run Parameters } \\
\hline \multicolumn{2}{|c|}{ ARDL result in Long run } & \multicolumn{2}{|c|}{ ARDL result in Short run } \\
\hline Variables & Coefficient & Variables & Coefficient \\
\hline $\mathbf{C}$ & $\begin{array}{c}0.95 \\
(3.85)\end{array}$ & $\mathbf{C}$ & $\begin{array}{c}0.005 \\
(0.017)\end{array}$ \\
\hline RD (-1) & $\begin{array}{c}-0.941 * * * \\
(0.291)\end{array}$ & DRD (-1) & $\begin{array}{c}-0.542 * * \\
(0.130)\end{array}$ \\
\hline ED (-1) & $\begin{array}{c}-14.089 * * * * \\
(4.606)\end{array}$ & DED (-1) & $\begin{array}{l}-4.694^{*} \\
(1.898)\end{array}$ \\
\hline MCWC & $\begin{array}{l}0.886 \\
(1.21) \\
\end{array}$ & DMCWC & $\begin{array}{c}-0.25 \\
(0.674)\end{array}$ \\
\hline PSDP & $\begin{array}{c}-0.371 * * \\
(0.195)\end{array}$ & DPSDP & $\begin{array}{l}-0.088 \\
(0.149)\end{array}$ \\
\hline PCI (-1) & $\begin{array}{l}-0.589 \\
(1.282)\end{array}$ & DPCI (-1) & $\begin{array}{l}-0.056 \\
(0.724)\end{array}$ \\
\hline \multirow[t]{2}{*}{ EDE } & $\begin{array}{l}0.509 * * \\
(0.1669)\end{array}$ & DEDE & $\begin{array}{l}1.30 \\
(0.1)\end{array}$ \\
\hline & & ECT (-1) & $\begin{array}{l}-0.823^{*} \\
(0.279)\end{array}$ \\
\hline
\end{tabular}

The elasticity of the decentralization of revenue and infant mortality rate is negative. The elasticity of the decentralization of expenditure and infant mortality rate is negative. It was confirmed by Robalino et al. (2002), the lower level (provinces) has low institutional capacity than center. The increase in public revenue sharing may create inefficiency and reduces the social services delivery of the state, as it seems 
from result, that the decentralization of revenue is less effective than the decentralization of expenditure. Tiebout (1956) stated that free movement of the resources between central government and local government, creates competition among them and finally both provides better public services. Additionally, Musgrave (1959) explored that local government has information advantage over central government regarding local priorities and needs, so it provides better social services. The elasticity of maternity center and child welfare center and infant mortality rate is positive. There is negative relationship between infant mortality rate and Maternity Center and Child Welfare center in short run, the government projects are only for short term but no focus on the long term. The health sector is decentralized to the provinces of the Pakistan, province has low capacity, and decentralization is ineffective without it (Robalino et al. 2002). The elasticity of the Public-sector development program and infant mortality rate is negative. When government spends a huge amount of its budget on public sector development, in which it improves in public services delivery. Therefore, there is inverse relation exist between PSDP and infant mortality rate. There is negative elasticity of the per capita income and infant mortality rate. It was confirmed by Sabir (2010), that the per capita income has positive impact on social services but it's insignificant in this research. The higher Per capita income indicates that a nation has high average income; it means that the nation spends a lot for health care and treatment of disease. It is insignificant because there is neither full fledge hospital nor trained doctors in rural areas, they might have to travel Quetta or Karachi for treatment. That's reason there is negative relationship between per capita income and infant mortality rate. The elasticity of expenditure on education and infant mortality rate is positive. Moreover, Ardiana (2005) examined negative relationship between infant mortality rate and education for USA. This finding seems contrary for developing countries; shah (2014) stated many of schools of Quetta and Panjgur were closed due to of threat and security issues of Balochistan. According to Ali (2015) in Dawn, after discovery of the ghost schools and ghost teachers now the ghost students are enrolled in Balochistan, in which are there are 234000 ghost students and moreover 600 ghost teachers were discovered. According to Balochistan development Forum (2015), the enrollment for the students for higher education institution of Balochistan was 11\% in 2012.

The significant and negative error term confirms the existence of the stable long run relationship among variables, according to Banneerjee et al. (1998). If there is any shock or disturbance then its speed of adjustment is $82.3 \%$ towards long run equilibrium after completion of a year.

\section{Fiscal Decentralization and Education Outcome}

To analyze the impact of fiscal decentralization on education outcome of Balochistan we have used following model.

$\log L R_{i t}=\beta_{0}+\beta_{1} \operatorname{logED} D_{i t}+\beta_{2} \operatorname{logRD} D_{i t}+\beta_{3} \log P G R_{i t}+\beta_{4} \operatorname{logPSDP} P_{i t}+\beta_{5} \log P C I_{i t}+\beta_{6} \operatorname{logEDE} E_{i t} e_{i t} \cdot E Q 2$

As given below table 6 states the optimal lag length is one by SIC and HQIC information criteria.

\begin{tabular}{cccc}
\hline \multicolumn{4}{c}{ Table: 6. Lag Length Selection Criteria } \\
\hline LAG & AIC & SIC & HQIC \\
\hline $\mathbf{1}$ & -28.924 & $-26.510^{*}$ & $-28.065^{*}$ \\
\hline $\mathbf{2}$ & -28.931 & -24.406 & -27.321 \\
\hline $\mathbf{3}$ & $-28.970^{*}$ & -22.333 & -26.608 \\
\hline & \multicolumn{2}{c}{ *Indicates lag order selected by criterion } \\
\hline
\end{tabular}

The F test statistic is greater the lower bound and upper bound values, it means that there is co-integration exist among the variables. The result of the $\mathrm{F}$ bound test is given below.

Table: 7. F Bound Test Results 


\begin{tabular}{|c|c|c|c|c|c|c|}
\hline \multirow[t]{2}{*}{ F -Test value } & \multirow[t]{2}{*}{$\begin{array}{c}\text { NO of } \\
\text { Parameters }\end{array}$} & \multirow[t]{2}{*}{ Lag length } & \multirow[t]{2}{*}{$\begin{array}{l}\text { Significance } \\
\text { level }\end{array}$} & \multicolumn{2}{|c|}{$\begin{array}{l}\text { Bound test } \\
\text { critical values }\end{array}$} & \multirow[t]{2}{*}{ Decision } \\
\hline & & & & I (0) & I (1) & \\
\hline \multirow[t]{3}{*}{8.822} & \multirow[t]{3}{*}{6} & \multirow[t]{3}{*}{3} & $1 \%$ & 2.88 & 3.99 & Co-integrated \\
\hline & & & $5 \%$ & 2.27 & 3.28 & Co-integrated \\
\hline & & & $10 \%$ & 1.99 & 2.94 & Co-integrated \\
\hline
\end{tabular}

After determining the co-integration among variables of the equation 2, the long run parameters are estimated on basis of the lag length selected through AIC, its results are given below.

Table: 8. Long Run Parameters \& Short Run Parameters

\begin{tabular}{cccc}
\multicolumn{5}{c}{ Table: 8. Long Run Parameters \& Short Run Parameters } \\
\hline \multicolumn{2}{c}{ ARDL result in Long run } & \multicolumn{2}{c}{ ARDL result in Short run } \\
\hline Variables & Coefficient & Variables & Coefficient \\
\hline C & $-0.904^{* * *}$ & C & -0.015 \\
& $(2.677)$ & DRD & $(0.028)$ \\
\hline RD & $-0.276^{* *}$ & & -0.385 \\
& $(0.091)$ & DED (-2) & $(0.222)$ \\
\hline ED (-2) & $4.994^{* *}$ & & $0.828^{* * *}$ \\
& $(2.34)$ & DPGR & $(3.123)$ \\
PGR & -0.519 & $-0.46^{*}$ \\
& $(0.443)$ & DPCI & $(0.265)$ \\
\hline PCI & $2.685 * * *$ & 0.018 \\
& $(0.808)$ & DPSDP & $(0.02)$ \\
\hline PSDP & 0.083 & 0.04 \\
& $(0.091)$ & DEDE (-1) & $(0.03)$ \\
\hline EDE (-1) & $0.23 * * *$ & -0.002 \\
& $(0.088)$ & ECT (-1) & $(0.01)$ \\
\hline & & & $-0.836^{* * *}$ \\
& & & $(0.321)$ \\
\hline & Standard Error are shown in brackets & \\
\hline
\end{tabular}

There is negative elasticity of the decentralization of revenue and literacy rate. The reason is provisional government has low administrative capability, inefficiency, diseconomies of scale and mismanagement. The elasticity of the decentralization of expenditure and literacy rate is positive. The elasticity of population growth rate and literacy rate is negative. It was confirmed by Akpan (2011), the developing countries are poor and high populated countries. These countries do not have infrastructure to accommodate and facilitate them better social services. The elasticity of the Public-sector development program and literacy rate is positive. It was confirmed by Sabir (2010) that the per capita income has positive impact on social services. The elasticity of per capita income and literacy rate is positive. The higher Per capita income indicates that a nation has high average income; it can spend a lot for education. The elasticity of expenditure on education and literacy rate is positive. It was confirmed by Mehmood (2010) that expenditure on education as percentage of GDP has positive impact on the social services delivery. The high expenditure on education indicates that higher national income spends a lot for education sector like teacher training and development, schools and colleges.

The result of short run parameters with error correction term is given below. If there is any shock or disturbance, then its speed of adjustment is $83.6 \%$ towards long run equilibrium after completion of a year. Revenue decentralization has negative impact on the literacy rate in short run and long run as well.

\section{Fiscal Decentralization and Unemployment Outcome}

To check the impact of fiscal decentralization on unemployment of Balochistan we have estimated the following model.

$\log U E R_{i t}=\beta_{0}+\beta_{1} \operatorname{logED} D_{i t}+\beta_{2} \operatorname{logRD} D_{i t}+\beta_{3} \log P G R_{i t}+\beta_{4} \operatorname{logEDE}$ it $+\beta_{5} \log P S D P_{i t}+e_{i t} \ldots . . . E Q 3$ The optimal lag length is one by two information criteria, SIC and HQIC. The result of each Information Criteria is given below. 
Table: 9. Lag Length Selection Criteria

\begin{tabular}{cccc}
\hline LAG & AIC & SIC & HQIC \\
\hline $\mathbf{1}$ & -24.763 & $-22.953^{*}$ & $-24.119^{*}$ \\
\hline $\mathbf{2}$ & -24.985 & -21.623 & -23.789 \\
\hline $\mathbf{3}$ & $-25.450^{*}$ & -20.538 & -23.702 \\
\hline & & *Indicates lag order selected by criterion
\end{tabular}

The co-integration exists among the variables, when the F test statistic is greater the lower bound value and upper bound value. The result of the F bound test is given below.

Table: 10. F Bound Test Results

\begin{tabular}{|c|c|c|c|c|c|c|}
\hline \multirow[t]{2}{*}{ F -Test value } & \multirow[t]{2}{*}{$\begin{array}{l}\text { NO of } \\
\text { Parameters }\end{array}$} & \multirow[t]{2}{*}{ Lag length } & \multirow[t]{2}{*}{$\begin{array}{l}\text { Significance } \\
\text { level }\end{array}$} & \multicolumn{2}{|c|}{$\begin{array}{l}\text { Bound test critical } \\
\text { values }\end{array}$} & \multirow[t]{2}{*}{ Decision } \\
\hline & & & & I (0) & I (1) & \\
\hline \multirow[t]{3}{*}{5.109} & \multirow[t]{3}{*}{5} & \multirow[t]{3}{*}{3} & $1 \%$ & 3.06 & 4.15 & Co-integrated \\
\hline & & & $5 \%$ & 2.39 & 3.38 & Co-integrated \\
\hline & & & $10 \%$ & 2.08 & 3.00 & Co-integrated \\
\hline
\end{tabular}

After determining the co-integration among variables of the equation 3, the long run parameters are estimated on basis of the lag length selected through AIC, its results are given below. The elasticity of the decentralization of revenue and unemployment rate is negative. The elasticity of the decentralization of expenditure and unemployment rate is negative.

\begin{tabular}{|c|c|c|c|}
\hline \multicolumn{4}{|c|}{ Table: 11. Long Run Parameters \& Short Run Parameters } \\
\hline \multicolumn{2}{|c|}{ ARDL result in Long run } & \multicolumn{2}{|c|}{ ARDL result in Short run } \\
\hline Variables & Coefficient & Variables & Coefficient \\
\hline $\mathrm{C}$ & $\begin{array}{c}-1.947 * * * \\
(0.56)\end{array}$ & $\mathrm{C}$ & $\begin{array}{c}0.000 \\
(0.026)\end{array}$ \\
\hline RD (-3) & $\begin{array}{c}-0.445^{* *} \\
(0.224)\end{array}$ & DRD (-3) & $\begin{array}{l}-0.237^{*} \\
(0.118)\end{array}$ \\
\hline ED (-2) & $\begin{array}{c}-3.221 * * \\
(1.703) \\
\end{array}$ & DED (-2) & $\begin{array}{c}-3.51 * * \\
(1.65)\end{array}$ \\
\hline PGR (-1) & $\begin{array}{c}3.714 * * * \\
(0.664)\end{array}$ & DPGR (-1) & $\begin{array}{l}4.971^{*} \\
(1.706)\end{array}$ \\
\hline EDE (-3) & $\begin{array}{l}0.081 \\
(0.09)\end{array}$ & DEDE (-3) & $\begin{array}{l}-2.87^{*} \\
(1.356)\end{array}$ \\
\hline \multirow[t]{2}{*}{ PSDP (-3) } & $\begin{array}{c}-0.506^{* * *} \\
(0.124)\end{array}$ & DPSDP (-3) & $\begin{array}{l}-0.225^{*} \\
(0.107)\end{array}$ \\
\hline & & ECT (-1) & $\begin{array}{c}-0.706^{* *} \\
(0.308)\end{array}$ \\
\hline
\end{tabular}

The elasticity of population growth rate and unemployment rate is positive. It was confirmed by Akpan (2011), there is inverse relationship between population growth rate and social services delivery. The elasticity of the Public-sector development program and unemployment rate is negative. The elasticity of expenditure on education and unemployment rate is positive. It was confirmed by Mehmood (2010) that expenditure on education as percentage of GDP has positive impact on the social services delivery but it is opposite of finding of Mehmood. According to Pakistan Bureau of Statistics (2016) stated that the unemployment rate of Balochistan is $4 \%$. Nearly 25000 students are graduated from various institutions every year but unfortunately only 2000 of them can get job. Additionally, Samad (2016) elaborated that public sector of Balochistan is not enough to support unemployed persons while there is only $6 \%$ quota of Balochistan in Federal organization, that is not enough to accommodate to minimize unemployment. Dawn (2016) stated that there are 35000 government jobs required to be filled but these jobs are still vacant and do not filled by provincial government before date of their lapse. That's reason of expenditure on education has positive and significant on the unemployment. The result of short run parameters with 
negative and significant error term is given below. If there is any shock or disturbance then its speed of adjustment is $79.5 \%$ towards long run equilibrium after completion of a year. There is negative impact of revenue decentralization and expenditure decentralization on the unemployment in short run and long run.

\section{Fiscal Decentralization and Poverty Outcome}

To check the impact of fiscal decentralization on poverty of Balochistan on the following model. $\operatorname{logPOV}_{\text {it }}=\beta_{0}+\beta_{1} \operatorname{logED} D_{i t}+\beta_{2} \operatorname{logRD} D_{i t}+\beta_{3} \log \mathrm{MI}_{\text {it }}+\beta_{4} \log P S D P_{i t}+\beta_{5} \log P G R_{i t}+e_{i t} \ldots . . . E Q 4$ According to Akaike Information Criteria, its minimum value is at second lag and its optimal lag length. The result of each Information Criteria is given below.

\begin{tabular}{cccc}
\hline \multicolumn{5}{c}{ Table: 12. Lag Length Selection Criteria } \\
\hline LAG & AIC & SIC & HQIC \\
\hline $\mathbf{1}$ & -23.646 & $-21.836^{*}$ & -23.002 \\
\hline $\mathbf{2}$ & $-24.371 *$ & -21.010 & $-23.789^{*}$ \\
\hline $\mathbf{3}$ & -23.995 & -19.082 & -22.175 \\
\hline & & $*$ Indicates lag order selected by criterion \\
\hline
\end{tabular}

The co-integration exists among the variables, when the F test statistic is greater the lower bound value and upper bound value. The result of the F bound test is given below.

Table 13. F Bound Test Results

\begin{tabular}{|c|c|c|c|c|c|c|}
\hline \multirow[t]{2}{*}{ F -Test value } & \multirow[t]{2}{*}{$\begin{array}{c}\text { NO of } \\
\text { Parameters }\end{array}$} & \multirow[t]{2}{*}{ Lag length } & \multirow[t]{2}{*}{$\begin{array}{c}\text { Significance } \\
\text { level }\end{array}$} & \multicolumn{2}{|c|}{$\begin{array}{l}\text { Bound test } \\
\text { critical values }\end{array}$} & \multirow[t]{2}{*}{ Decision } \\
\hline & & & & I (0) & I (1) & \\
\hline \multirow[t]{3}{*}{6.107} & 5 & 2 & $1 \%$ & 3.06 & 4.15 & Co-integrated \\
\hline & & & $5 \%$ & 2.39 & 3.38 & Co-integrated \\
\hline & & & $10 \%$ & 2.08 & 3.00 & Co-integrated \\
\hline
\end{tabular}

After determining the co-integration among variables, the long run parameters are estimated on basis of the lag length selected through AIC, its results in tabulation form are given below.

\begin{tabular}{|c|c|c|c|}
\hline \multicolumn{4}{|c|}{ Table: 14. Long Run Parameters \& Short Run Parameters } \\
\hline \multicolumn{2}{|c|}{ ARDL result in Long run } & \multicolumn{2}{|c|}{ ARDL result in Short run } \\
\hline Variables & Coefficient & Variables & Coefficient \\
\hline $\mathbf{C}$ & $\begin{array}{c}0.822 \\
(0.195)\end{array}$ & $\mathbf{C}$ & $\begin{array}{l}0.0001 \\
(0.004)\end{array}$ \\
\hline RD (-2) & $\begin{array}{l}-0.185 \\
(0.195)\end{array}$ & DRD (-2) & $\begin{array}{l}-0.075^{* * * *} \\
(0.026)\end{array}$ \\
\hline ED (-2) & $\begin{array}{c}-7.383 * * \\
(3.633)\end{array}$ & DED (-2) & $\begin{array}{l}-1.189 * \\
(0.305)\end{array}$ \\
\hline PSDP & $\begin{array}{l}-0.099 \\
(0.105)\end{array}$ & DPSDP & $\begin{array}{l}-0.023 \\
(0.023)\end{array}$ \\
\hline MI (-2) & $\begin{array}{l}0.634^{*} \\
(0.233)\end{array}$ & DMI (-2) & $\begin{array}{c}0.025 \\
(0.023)\end{array}$ \\
\hline \multirow[t]{2}{*}{ PGR (-1) } & $\begin{array}{c}2.33 \\
(0.577)\end{array}$ & DPGR (-1) & $\begin{array}{c}0.467 \\
(0.297)\end{array}$ \\
\hline & & ECT (-1) & $\begin{array}{l}-0.927 * * * \\
(0.257)\end{array}$ \\
\hline \multicolumn{4}{|c|}{$\begin{array}{c}* \text { shows significance at } 10 \% \text { level, ** significance at } 5 \% \text { level, *** significance at } 1 \% \text { level } \\
\text { Standard Error are shown in brackets }\end{array}$} \\
\hline
\end{tabular}


between poverty rate and misery index. The elasticity of the Public-sector development program and poverty rate is negative. The elasticity of population growth rate and poverty rate is positive The short run results are given below table 14. If there is any shock or disturbance then its speed of adjustment is $95.8 \%$ towards long run equilibrium after completion of a year, the results diagnostic tests are given below.

\begin{tabular}{|c|c|c|c|c|c|c|c|c|}
\hline \multicolumn{9}{|c|}{ Table: 15 . Diagnostic Tests } \\
\hline \multirow[b]{2}{*}{$\begin{array}{c}\text { Diagnostic } \\
\text { Test }\end{array}$} & \multicolumn{2}{|c|}{ Equation 1} & \multicolumn{2}{|c|}{ Equation 2} & \multicolumn{2}{|c|}{ Equation 3} & \multicolumn{2}{|c|}{ Equation 4} \\
\hline & $\begin{array}{l}\text { Coefficient } \\
\text { (long run) }\end{array}$ & $\begin{array}{l}\text { Coefficient } \\
\text { (short run) }\end{array}$ & $\begin{array}{l}\text { Coefficient } \\
\text { (long run) }\end{array}$ & $\begin{array}{l}\text { Coefficient } \\
\text { (short run) }\end{array}$ & $\begin{array}{l}\text { Coefficient } \\
\text { (long run) }\end{array}$ & $\begin{array}{l}\text { Coefficient } \\
\text { (short run) }\end{array}$ & $\begin{array}{l}\text { Coefficient } \\
\text { (long run) }\end{array}$ & $\begin{array}{l}\text { Coefficient } \\
\text { (short run) }\end{array}$ \\
\hline R square & 0.936 & 0.66 & 0.998 & 0.514 & 0.948 & 0.801 & 0.949 & 0.825 \\
\hline $\begin{array}{l}\text { Adjusted } \\
\text { R square }\end{array}$ & 0.914 & 0.52 & 0.997 & 0.281 & 0.90 & 0.579 & 0.923 & 0.715 \\
\hline F statistic & $42.746 * * *$ & $4.765 * * *$ & $1567 *$ & $2.20 * *$ & $19.512 * * *$ & $3.613 * * *$ & $36.240 * * *$ & $7.63 * * *$ \\
\hline $\begin{array}{c}\text { LM test } \\
\text { F statistic }\end{array}$ & \multicolumn{2}{|c|}{0.184} & \multicolumn{2}{|c|}{0.424} & \multirow{2}{*}{\multicolumn{2}{|c|}{0.424}} & \multirow{2}{*}{\multicolumn{2}{|c|}{0.2189}} \\
\hline \multicolumn{6}{|c|}{$*$ shows significance at $10 \%$ level, $* *$ significance at $5 \%$ level, $* * *$ significance at $1 \%$ level } & & & \\
\hline
\end{tabular}

The R square tells goodness of fitness of model is satisfied in both short run and long run. F statistic shows the overall significance of the model. LM test shows there is no serial correlation in the model for all equation. Cumulative sum of residuals (CUSUM) test indicates that all the parameters of the four equations are stable at $5 \%$ significance level, figure 1 is given below.

Fiscal decentralization \& unemployment rate

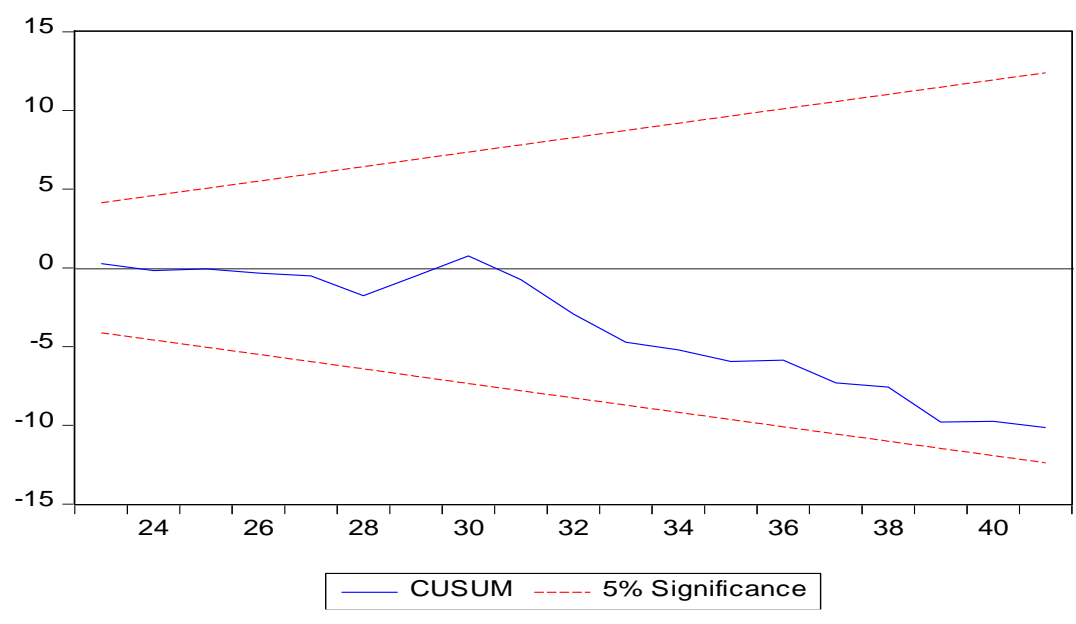

Fiscal decentralization \& poverty rate

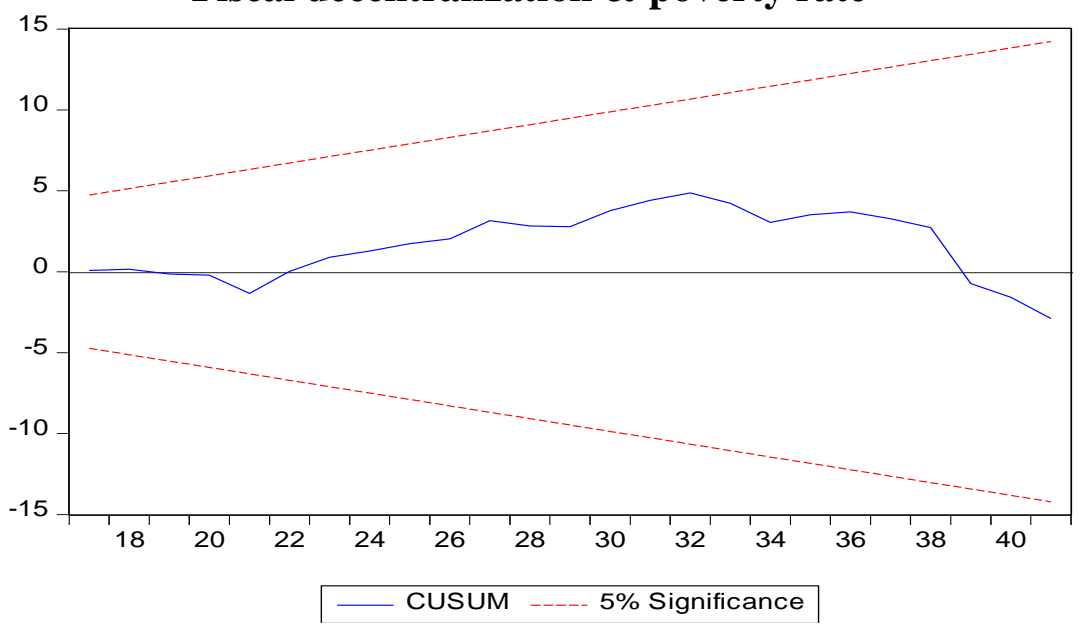


Fiscal decentralization \& health outcome

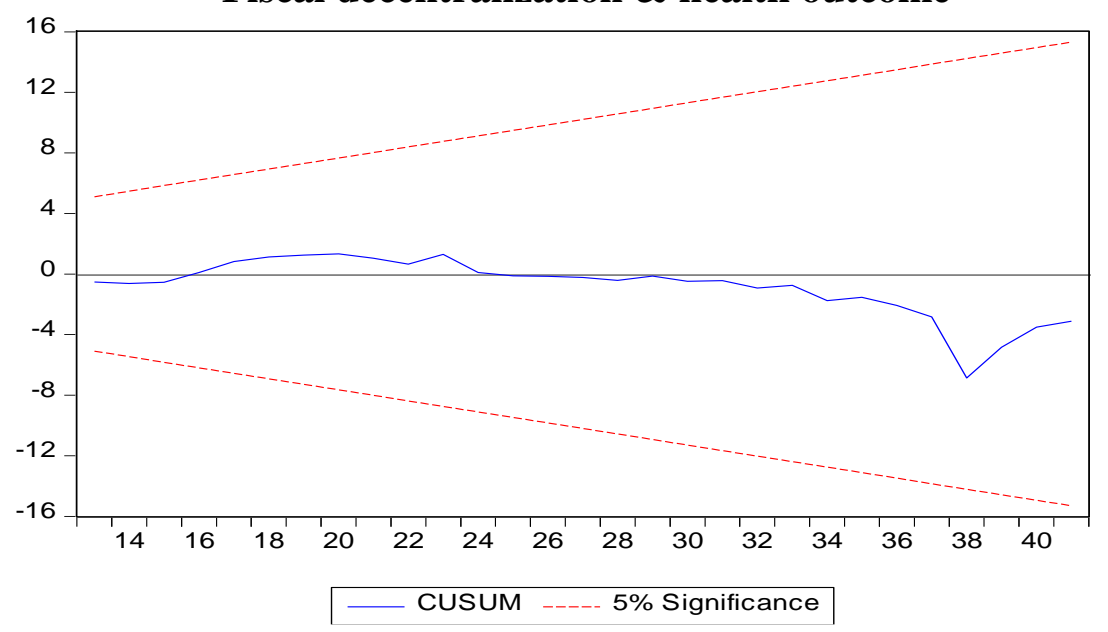

Fiscal decentralization \& education outcome

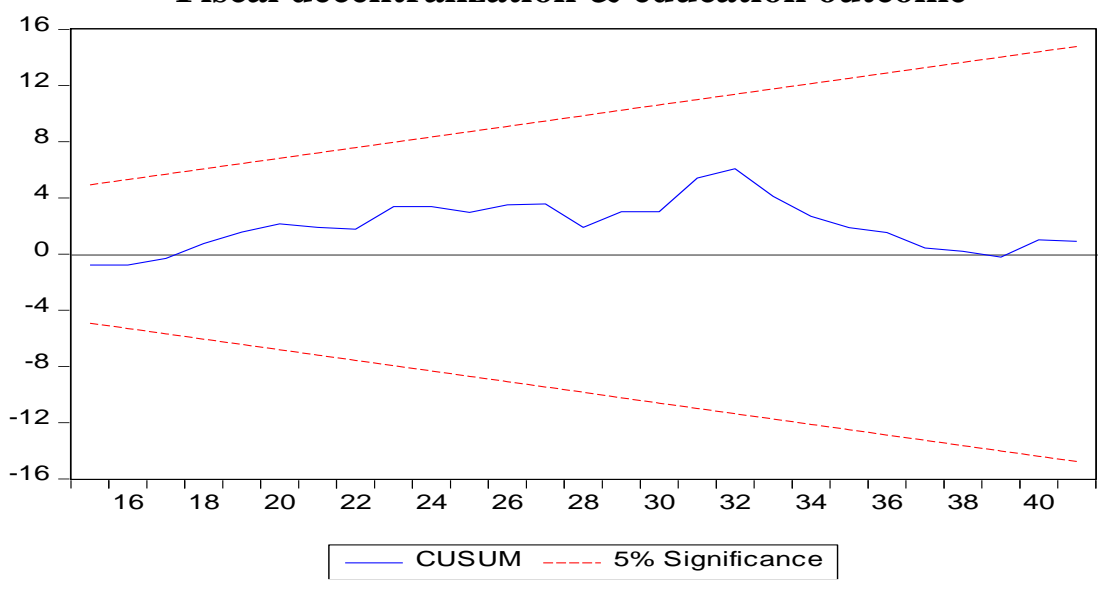

Figure: 1. Stability of Parameters

\section{Conclusion and Recommendation}

The fiscal decentralization has positive impact on social services provisions, such as if FD increases as a result infant mortality rate decreases, literacy rate increases, unemployment and poverty get reduced. Robalino et al. (2002), the lower level (provinces) has low institutional capacity than center, the increase in public revenue sharing may create inefficiency and reduces the social services delivery of the state. That reason, the decentralization of revenue is less effective than the decentralization of expenditure in case of Balochistan.

The following policy is recommended on basis of the research findings.

* The fiscal decentralization is better for providing better social services as local government familiar with local needs and priorities and local government has information advantage as compare to central government. The free movement of the resources between central government and local government creates competition among them and finally both provide better public services.

* Provincial level government has low institutional capacity and diseconomies of scale than center government; the increase in public revenue sharing may create inefficiency and reduces the social services delivery of the state

* This study motivates the expenditure decentralization as effective tool for delivery of social services because as local government familiar with local needs and priorities and local government has information advantage as compare to central government. 
* The province should need to work on emergency basis to improve administrative efficiency, more accountability, infrastructure and human development in-order FD brings more favorable for Balochistan.

\section{References}

Azfar, O., Kahkonen, S., Lanyi, A., Meagher, P., \& Rutherford, D. (1999). Decentralization, governance and public services: the impact of institutional arrangements. Centre for Institutional Reform and the Informal Sector, 1-37.

Asch, S. M., Kerr, E. A., Keesey, J., Adams, J. L., Setodji, C. M., Malik, S., \& McGlynn, E. A. (2006). Who is at greatest risk for receiving poor-quality health care? New England Journal of Medicine, 354(11), 1147-1156.

Ahmed, M., \& Baloch, A. (2014). Political economy of fiscal decentralization in Pakistan: an analytical study. Gomal University Journal of Research, 30(2).

Ahmed, M., and Lodhi, A. salam. (2013). Impact of fiscal decentralizations on education and healthcare, outcomes: empirical evidence from Pakistan. J. App. Em. Sc 4 (2).

Ahmed, M. (2013). Fiscal decentralization and Political economy of Poverty Reduction: theory and Evidence from Pakistan (Doctoral dissertation, Durham University).

Akpan, Eme. O. (2011). Fiscal decentralization and social outcomes in Nigeria. European Journal of Business and Management, 3, (4).

Akpan, E. O. (2011). Fiscal decentralization and social outcomes in Nigeria. European Journal of Business and Management, 3(4), 167-183.

Asfaw, A., Frohberg, K., James, K. S., \& Jütting, J. (2007). Fiscal decentralization and infant mortality: empirical evidence from rural India. The Journal of Developing Areas, 41(1), 17.

Ahmed, M., \& Ahmad, I. (2015). The Political Economy of Decentralization and Access to Pro-poor Social Services Delivery in Pakistan/Comments. Pakistan Development Review, 54(4), 471.

Bikam, P., Rapodile, D., \& Chakwizira, J. (2015). Can Fiscal Decentralization Address Water and Sanitation Infrastructure Backlogs in South Africa: The Case Study of Municipal Infrastructure Grant in Mahikeng and Thulamela Local Municipalities. International Journal, 10.

Banerjee, A., Dolado, J., \& Mestre, R. (1998). Error-correction mechanism tests for co-integration in a single-equation framework. Journal of time series analysis, 19(3), 267-283.

Bengali Kaiser and Ahmed Qazi Masood (2001) Stabilization Policy vs. Growth oriented Policy: Implication for the Pakistan Economy. The Pakistan Development Review, 40, (4): 453-466.

Bird, R. M. (1993). Threading the fiscal labyrinth: some issues in fiscal decentralization. National tax journal, 207-227.

Busemeyer, M. R. (2007). Determinants of public education spending in 21 OECD democracies, 19802001. Journal of European Public Policy, 14(4), 582-610.

Cheema, A., Khwaja, A. I., \& Qadir, A. (2006). Local government reforms in Pakistan: context, content and causes. Decentralization and local governance in developing countries: A comparative perspective, 257-84.

Collins, M., Ramshaw, L., Hajič, J., \& Tillmann, C. (1999, June). A statistical parser for Czech. In Proceedings of the 37th annual meeting of the Association for Computational Linguistics on Computational Linguistics (pp. 505-512). Association for Computational Linguistics.

Davoodi, H., \& Zou, H. F. (1998). Fiscal decentralization and economic growth: A cross-country study. Journal of Urban economics, 43(2), 244-257.

De Mello, L. R., \& Barenstein, M. (2001). Fiscal decentralization and governance: a cross-country analysis.

Ekpo, A. H. (2008). Decentralization and service delivery: A framework. African Economic Research Consortium, Nairobi.

Faridi, M. Z., \& Nazar, R. (2013). Impact of Fiscal Autonomy on Poverty in Pakistan. Pakistan Journal of Commerce \& Social Sciences, 7(1).

Fesler, J. W. (1965). Approaches to the Understanding of Decentralization. The Journal of Politics, 27(3), 536-566. 
Fjeldstad, O. H. (2001). Fiscal decentralization in Tanzania: For better or for worse? Chr. Michelsen Institute.

Fiva, J. H. (2006). New evidence on the effect of fiscal decentralization on the size and composition of government spending. Finanz Archiv: Public Finance Analysis, 62(2), 250-280.

Faridi, M. Z., Chaudhry, I. S., Hanif, I., \& Ansari, F. N. (2012). Fiscal Decentralization and Employment in Pakistan. International Business Research, 5(11), 54.

Ghaus, A. F. Aisha and Hafiz A. Pasha. (1994). Dynamic Budgetary Consequences of the 1991 NFC Award. The Pakistan Development Review, 33(4), 627645.

Gamkhar, S., \& Shah, A. (2007). The impact of intergovernmental fiscal transfers: a synthesis of the conceptual and empirical literature. Intergovernmental fiscal transfers: principles and practice, 225-258.

Government of Pakistan, 2009, Report of the National Finance Commission. National Finance Commission Secretariat. Islamabad.

Government of Pakistan, 1991, Report of the National Finance Commission. National Finance Commission Secretariat. Islamabad.

Government of Pakistan, 1997, Report of the National Finance Commission. National Finance Commission Secretariat. Islamabad.

Government of Pakistan, 2006a, The Gazette of Pakistan, "An Order further to amend the Distribution of Revenues and Grants-in-Aids Order, 1997”. Order No.1 of 2006. Ministry of Law, Justice and Human Rights.

Iqbal, N., \& Nawaz, S. (2010). Fiscal decentralization and macroeconomic stability: Theory and evidence from Pakistan. MPRA, 27184.

Jaffery, B., and Sadaqat, M. (2006). NFC AWARDS Commentary and Agenda, Pakistan Economic and Social Review, 44 (2), 209-234.

Kardar, S. (2006). Local Government Finance in Pakistan Post 2001. Lahore Journal of Economics, 11.

Khattak, N. U. R., Ahmad, I., \& Khan, J. (2010). Fiscal decentralization in Pakistan. The Pakistan Development Review, 49(4-II), 419.

King, D., \& Ma, Y. (2001). Fiscal decentralization, central bank independence, and inflation. Economics Letters, 72(1), 95-98.

Khaleghian, P. (2004). Decentralization and public services: the case of immunization. Social science \& medicine, 59(1), 163-183.

King, E., \& Ozler, B. (1998). What's decentralization got to do with learning? The case of Nicaragua's school autonomy reform. Development Economics Research Group, Working Paper Series on Impact Evaluation of Education Reforms, 9.

Lin, J. Y., \& Liu, Z. (2000). Fiscal decentralization and economic growth in China. Economic development and cultural change, 49(1), 1-21.

Litvack, J. I., Ahmad, J., \& Bird, R. M. (1998). Rethinking decentralization in developing countries. World Bank Publications.

Landreth, S. (2015). Universal access to the water and sanitation services, the role of the political will in implementation practices, a study of Pakistan and India. University of Colorado, Boulder CU Scholar.

Mehmood, R. (2010). Impact of Fiscal Decentralization on Human development: A Case Study of Pakistan, 26th Annual General Meeting and Conference, university of Karachi.

Mehmood, R., Sadiq, S., \& Khalid, M. (2010). Impact of Fiscal Decentralization on Human Development: A Case Study of Pakistan. The Pakistan Development Review, 513-530.

Musgrave, R. A. (1959). Theory of public finance; a study in public economy. 